\title{
Integrating the Theory of Constraints and Six Sigma: Process Improvement Implementation
}

\author{
Erhan Ekleş1 $\odot$, Mevhibe Ay Türkmen² $\odot$
}

\begin{abstract}
Businesses apply many management philosophies aiming to manage processes effectively, eliminate bottlenecks and improve their process performance. The most important of these philosophies are the Theory of Constraints and the Six Sigma. These are used separately in process improvement and performance enhancement in many businesses. Recently, an integration model approach of two philosophies has been examined in the literature in an effort to reduce their weaknesses and increase their strong effects. In the literature, three different approaches are identified for the integration model of Theory of Constraints and Six Sigma. In this study, the integration model of Jin, Abdul-Razzak, Elkassabgi, Zhou, \& Herrera, (2009) was applied in an industrial enterprise in order to identify and eliminate the root causes of the decline in sales figures. It has been revealed that the integration model can help to identify and eliminate these root causes and how it benefits the business. As a result of the application, an improvement in production cost by $1.56 \%$ and $3.55 \%$ and an increase in $\sigma$ value from 1.4 to 2.3 were determined. With this model, constraints in the production process were determined, managed and eliminated.
\end{abstract}

Keywords

Theory of Constraints, Six Sigma, Integration Model, Power Cable Production

\section{Introduction}

On the basis of protecting their assets and to ensure continuity, companies should manage their processes effectively, eliminate bottlenecks and improve their process performance. In order to perform those actions, they apply many management philosophies. One of them is the Theory of Constraints (TOC), which Goldratt mentioned in his book "Goal" written in 1984, and another is the Six Sigma (6б) philosophy developed by Motorola in the 1980s. The popularity of these concepts continues in today's business world and literature.

The purpose of the TOC is to increase the capacity of the whole system with the purpose of reaching businesses' goals and targets now and in the future. It has been seen that studies

1 Corresponding Author: Erhan Ekleş (Master), Pamukkale University, Institute of Social Sciences, Production Management and Marketing MSc Program, Denizli, Turkey. E-mail: eekles18@posta.pau.edu.tr ORCID: 0000-0002-3853-6981

2 Mevhibe Ay Türkmen (Assoc. Prof. Dr.), Pamukkale University, Faculty of Economics and Administrative Sciences, Department of Business Administration, Denizli, Turkey. E-mail: mturkmen@pau.edu.tr ORCID: 0000-0003-2365-6726

To cite this article: Ekles, E., \& Ay Turkmen, M. (2022). Integrating the Theory of Constraints and Six Sigma: Process Improvement Implementation? Istanbul Business Research, 51(1) Advanced Online Publication. http://doi.org/10.26650/ibr.2022.51.938481 
in the literature about the TOC are conceptual, the application of TOC principles to different theoretical problems, the comparison of TOC philosophy with different systems and TOC applications (Rahman, 1998). The TOC has been applied to many fields; the manufacturing sector (Ünal, Tanış \& Küçüksavaş, 2005; Demircioğlu \& Akkaya, 2016; Wolniak, SkotnickaZasadzien, \& Zasadzien, 2018; Urban \& Rogowska, 2018; Rojas, Jurado, \& Londono, 2018; Sorkun, 2018; Urban, 2019; Garza, et al., 2019; Akçimen \& Antmen, 2019; Aiastui, Perez de Eulate, \& Guisasola, 2020; Al-Fasfus, Hamza, \& Elkotayni, 2020; Karakoç \& Ş1k, 2021; Mahdi, Abboud \& Hussain, 2021), the service sector (Taştan \& Demircioğlu, 2015; Akbulut \& Ertan, 2015; Ayanoğlu \& Şakar, 2015; Yükçü \& Yüksel, 2015; Escobar, Vega, \& Zamora, 2016; Grida \& Zeid, 2019), supply chains (Harish, 2019; Kelly \& Germain, 2020; Huang, Lu \& Dang, 2021), project management (Mishra, 2020; Sarkar, Jha \& Patel, 2021), product mix decisions (Ünal et al., 2005; Kaygusuz, 2005; Mehdizadeh \& Jalili, 2018) and human resources management (Tekin \& Şahin, 2014; Alghaithi \& Sartawi, 2020).

$6 \sigma$ is a systematic approach that aims to increase business profitability, performance, production and customer satisfaction, as well as to reduce the operational costs of the business. The studies about $6 \sigma$ are classified within the framework of descriptive, experimental, conceptual and literature review (Nonthaleerak \& Hendry, 2006; Ninerola, Rebull \& Lara, 2021). The method is described in the literature on the manufacturing sector (Koch, Yang, \& Gu, 2004; Erdiller \& Orbak, 2005; Hsu, Pearn, \& Wu, 2008; Boangmanalu, Abigail, Sembiring, \& Tampubolon, 2020; Sithole \& Nyembwe, 2020; Rebull, et al., 2020) and service sector (Dakhil, 2019; Stanivuk, et al., 2020; Abid, et al., 2020; Ali, 2020) applications; in the context of its relationship with Total Quality Management (TQM) (Yang, 2004; Çalışkan, 2006; Bircan \& Köse, 2012; Elmac1, Uslu, \& Tutkavul, 2013) and lean (Edgeman \& Bigio, 2004; Turan \& Turan, 2019; Ikumapayi, et al., 2020; Gholami, et al., 2021; Costa, et al., 2021); it is also seen that it is the subject in conceptual and descriptive frameworks (Pyzdek, 2000; Rasis, Gitlow, \& Popovic, 2002; Rowlands, 2003; Coronado \& Antony, 2004; Antony, 2004; Ülgen,

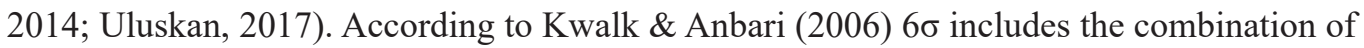
five methods; TQM or continuous quality improvement, customer focus, multiple analysis methods, financial performance and project management (Lee \& Chang, 2012, p.453).

Both methods have similar and also different aspects (Table 1). The TOC deals with the methods, procedures and paradigms that are interfering with the processes, rather than concentrating on the technical constraints which $6 \sigma$ is better at detecting in the processes (Lee \& Chang, 2012, p.454). While $6 \sigma$ deals with technical issues with quantitative tools, the TOC tries to find solutions with more qualitative analysis. While $6 \sigma$ is located in the chain between supplier and customer in the system, the TOC is mostly located between the whole system and the weakest link which has the most limited capacity in the system. While the value approach of $6 \sigma$ is meeting the demands and expectations of the customer, the TOC's value approach is mostly based on the use of the constraints in the system with the aim of being be- 
neficial at the highest level. By taking into account both theories' fundamental assumptions, implementation steps, effects on the organization and shortcomings, Nave (2002) emphasizes that if the organization focuses on minimazing fluctuation and standardizing process outputs, it should concentrate on $6 \sigma$; if it focuses on constraints and increasing the level of output, it should concentrate on TOC.

Table 1

Comparisons of TOC and $6 \sigma$

\begin{tabular}{|c|c|c|}
\hline & $6 \sigma$ & TOC \\
\hline Aim & Minimizing fluctuations & Managing constraints \\
\hline $\begin{array}{l}\text { Implementation } \\
\text { Plan }\end{array}$ & $\begin{array}{l}\text { 1.Define } \\
\text { 2.Measure } \\
\text { 3.Analyze } \\
\text { 4.Improve } \\
\text { 5.Control }\end{array}$ & $\begin{array}{l}\text { 1.Identify the constraint } \\
\text { 2.Exploit the contstraint } \\
\text { 3.Subordinate to the constraint } \\
\text { 4.Elevate the constraint } \\
\text { 5.Back to step } 1\end{array}$ \\
\hline Focus point & Problem oriented & Constraint oriented \\
\hline Assumptions & $\begin{array}{c}\text { There is a problem. } \\
\text { Numerical valuations are available. If fluctu- } \\
\text { ations are minimized, the output level would } \\
\text { increase. }\end{array}$ & $\begin{array}{l}\text { Emphasis on production speed and throughput. } \\
\text { Existing systems are applied. All processes are } \\
\text { independent from each other. }\end{array}$ \\
\hline First Impact & Output quantity standardize & Quick output \\
\hline $\begin{array}{l}\text { Secondary } \\
\text { Impact }\end{array}$ & $\begin{array}{c}\text { Lower improvidence. } \\
\text { Quick output. } \\
\text { Lower level of stock. } \\
\text { Performance measurement for managers. } \\
\text { Improved quality. }\end{array}$ & $\begin{array}{l}\text { Lower improvidence. } \\
\text { Lower level of stock. } \\
\text { Output cost accounting. } \\
\text { Performance measurement system. } \\
\text { Improved quality. }\end{array}$ \\
\hline Reviews & $\begin{array}{c}\text { The relationship of systems with each other is } \\
\text { ignored. } \\
\text { Processes develop independently. }\end{array}$ & $\begin{array}{l}\text { Minimum employee input and contribution. } \\
\text { Data analysis has not been evaluated. }\end{array}$ \\
\hline
\end{tabular}

Ref: (Nave, 2002, p.77)

\section{Conceptual Framework}

\section{The Theory of Constraints and Six Sigma Integration Model}

Although the TOC and $6 \sigma$ are different philosophies, many businesses can use both of them as their method of finding solutions. Some managers are aiming to speed up the workflow and minimize fluctuations that can be seen in output by combining those two philosophies. In the literature three different integration models have been identified.

The Jin et al. (2009) Integration Model: The Fundament of this model is; while $6 \sigma$ creates in-depth solutions for complex problems the TOC identifies bottlenecks in the system and tries to eliminate them. This method is recommended for businesses which do not have enough budget to apply the $6 \sigma$ method in cases where removing the constraint determined in the next processes will not provide a meaningful improvement. The best solution is the application of the $6 \sigma$ at the point where the capacity shrinks and bottleneck occurs in a facility. In this model, the implementation plans of both philosophies are applied separately and then combined using these steps (Figure 1). 
Identify the constraint; here is the first step where we reach the basic problem by using Thinking Process (TP) tools and analyzing its impact on the organization. Workflow charts and value flow maps are used to determine system constraints.

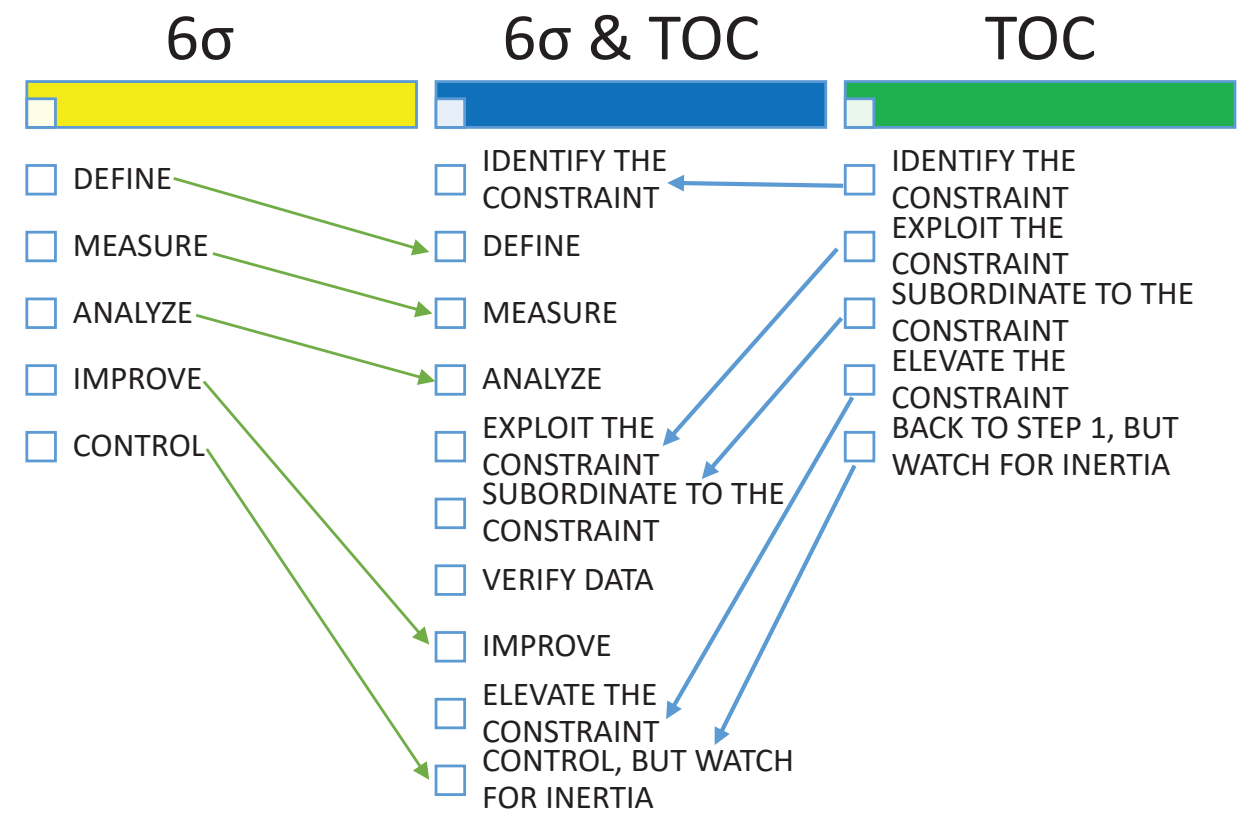

Figure 1. Jin et al. Integration Model

Ref: (Jin, et al., 2009, s.87)

Define; this is the starting point of $6 \sigma$. Due to the limited budget, only the most obvious Critical Quality Characteristics (CTQ) are taken into account. CTQ's are parameters that define internal and external customers' demands and preferences.

Measure; this is the step where to define the chosen CTQ's after constraints. Defined criteria should be understandable by all business personnel. Histogram, Pareto Analysis, Quality Control Charts are the most common statistical tools in this step.

Analyze; this step covers all activities to find the root cause of CTQ's. The importance of this step is to find a solution to the problem to be developed in the next steps. Workflow charts, fishbone diagram, failure mode and effect analysis (FMEA) and regression analysis can be used.

Exploit the constraint; at this stage we go back to the constraint and try to maximize the usage of it. Due to having different type of contsraints, different tools can be used in this stage.

Subordinate to the constraint; in here, all processes are designed according to the constraint. It is attempted to reduce the workload in front of the bottlenecks. Value flowcharts or drum-buffer-rope methods can be used. 
Verify data; with the object of achieving improvement, we should verify data. We should verify whether there have been any changes in the CTQs in the previous stages when the constraint was managed and the system was designed according to the constraint.

Improvement; at this stage, it is attempted to make the most appropriate improvement by using a Design of Experiment (DOE) application. DOE tries to reveal relationships between inputs and outputs in production processes by using statistical tools and mathematical models.

Elevate the constraint; aiming to increase workforce or to make processes more effective, necessary investments are done.

Control, Back to Stage 1; this step is necessary for continuous improvement. To observe the progress, team members should constantly monitor results. When a new constraint is detected, the model is restarted.

Ehie and Sheu (2005) Integration Model: According to Ehie and Sheu (2005), there are three advantages of integrating the TOC and the $6 \sigma$;

- Constraints are analyzed, measured and controlled by using statistical methods. With this approach, problems and decisions are understood by the whole organization.

- The fact that the bottleneck is the first point to be analyzed will result in a greater financial gain.

$-6 \sigma$ gets support from the TOC in order to be adopted to the whole system.

From the point of view of this integration model; the TOC serves as a framework for continuous improvement while the $6 \sigma$ helps to implement changes by providing specific statistical tools and engineering techniques.

Lee and Chang (2012) Integration Model: By examining the TOC, the $6 \sigma$ and root cause analysis (RCA) comparatively, Lee and Chang (2012) investigated the specified strengths and weaknesses of these methods can complement each other.

In this model, the TOC defines constraints and outputs by acting as a framework and with $6 \sigma$, specific processes are defined by using statistical tools and techniques for development. With RCA, in an attempt to find root causes of the problems that occur in the processes, necessary methods were provided for the project team by brainstorming.

\section{Application of the TOC and 6\% Integration Model}

\section{Purpose of the Application}

In the literature review, it has been determined that the TOC and $6 \sigma$ are applied separately in many production facilities. On the other hand, there are not enough studies on the integration 
model application. One of the purposes of this study is to be among the few sources in the literature on a similar subject and to contribute to it. The main purpose of this application is; to determine the solutions following the application steps of the TOC and $6 \sigma$ integration model and the implementation of the solution into the low performance that occurs during the production steps. This application was performed in one of the biggest power cable manufacturers called XYZ A.Ş. which was established in the 1970s and operates 3 shifts a day with 200 employees. It exports approximately $80 \%$ of all its production to Europe and the Middle-East.

\section{Definition of the Problem}

The Medium voltage (MV) product group is used mainly in construction and infrastructure projects. It is the product group that gives the fastest response to the growth of the construction sector. According to the construction turnover index of the Turkish Statistical Institute (TÜIK), taken from the database of between 2017 and 2019 when the export figures were examined 1 , it was found that there was a significant increase in this period. It is expected that an increase in sales of this MV product group in both the domestic and export markets between 2017 and 2019. However, MV cable sales of the company were $45 \%$ of total sales in 2017, and it decreased to $35 \%$ and $20 \%$ in 2018 and 2019 respectively. Although the production capacity for MV products was sufficient to reach the targeted sales figures, it could not be achieved due to the competition. XYZ A.Ş. aims to increase its sales figures in this group for 2020 and beyond. In line with this goal, it is aimed to determine whether there is any constraint in the MV production process, to analyze it, to design the process according to the constraint and to make the necessary improvement studies.

\section{Integration Model Application}

Among the integration models identified in the literature review, The Jin et al. (2009) TOC and $6 \sigma$ integration model and its implementation steps will be used for the improvement. The reason for choosing this model is that the application steps are more detailed compared to the other two models and the MV production process, which is planned to be improved, consists of different process. The company would like to use this model because it does not have enough budget to apply $6 \sigma$ in the situation where removing the constraint cannot provide a meaningful improvement.

\section{Identify the Constraint}

In order to define basic problem and examine its effect on the process, TOC's TP tolls were used. A project team consisting of a Sales Manager, an MV Line production Supervisor, a Quality Control (QC) Manager and a Factory Plant Manager was formed to determine the reasons for this decrease. The main reasons have been defined by the team as follows;

1 Export Amount (kg) / Amount (USD) ; (2017) 7,734,647 kg / 38,581,829 USD, (2018) 6,314,111 kg / 34,801,573 USD, (2019) 11,149,647 kg / 50,332,063 USD (Reference; TUIK, https://iz.tuik.gov.tr/\#/showcase/) 
- Not being able to meet the expectations of customers in the sales price of the product and not being able to compete with the prices offered by other manufacturers,

- Failing to meet the quality expectations of the customers,

- Inability to deliver products on time.

Between 2017 and 2019, it was determined that, a total of 62 customer complaints were received from external customers and none of them were related to the MV product group. In the same period, during the general inspection carried out by international quality organizations, none of the non-conformity was received for the same product group. Capacity occupancy rates of the MV production line were; 2017 - 31.60\%, 2018 - 38.90\%, 2019 - 29.40\%. In the light of these data and information, we can generalize that the main reason for the decrease in sales should be the failing to meet customer expectations in the sales price and the inability to compete with prices offered by other manufacturers.

According to the data obtained from the sales manager; the costs of MV products consist of a raw material cost (94-95\%), a labor cost and electricity expenses (4-5\%) and general expenses (1\%). Therefore, it has been decided to define high total production expenses including raw materials and production process as a constraint. Aiming to compete with product sales prices, necessary improvements should be made to reduce these costs.

To examine this constraint and to reach to the root causes of these effects, one of the TP tools Current Reality Tree (CRT) was used. After meeting with the MV production line supervisor, employees and the QC Manager, low production speed, high raw material costs, the long length of the pre-production preparation period and a high scrap amount per unit, have been identified as effects that increase the production cost. A CRT was formed by analyzing the effect-cause-effect relationship of those effects (Figure 2). The root causes were identified as follows;

- The MV production line is not suitable for alternative production technologies.

- There is no Gravimetric Dosing (GD) technology.

- The end product variety is high.

Since MV products are used in different environmental conditions, different projects and applications, many different types of cable have to be produced. Hence, we can say that the high end product variety of MV product groups are natural to it. When CRT is examined, it is seen that since the amount of raw material used cannot be determined it takes time to adjust the insulation thickness which increases the production preparation time and decreases the production speed. Considering the constraint concept, the adjustment of insulation thickness process has been defined as a bottleneck. Since the raw material amount can be adjusted 
easily with GD technology, this bottleneck will be improved. Again, with the same GD technology, different types of products can be used. Thanks to this technology, raw materials can be controlled at every stage of production, and production costs can be reduced by using alternative raw materials. As a conclusion, not having GD technology is considered a constraint.

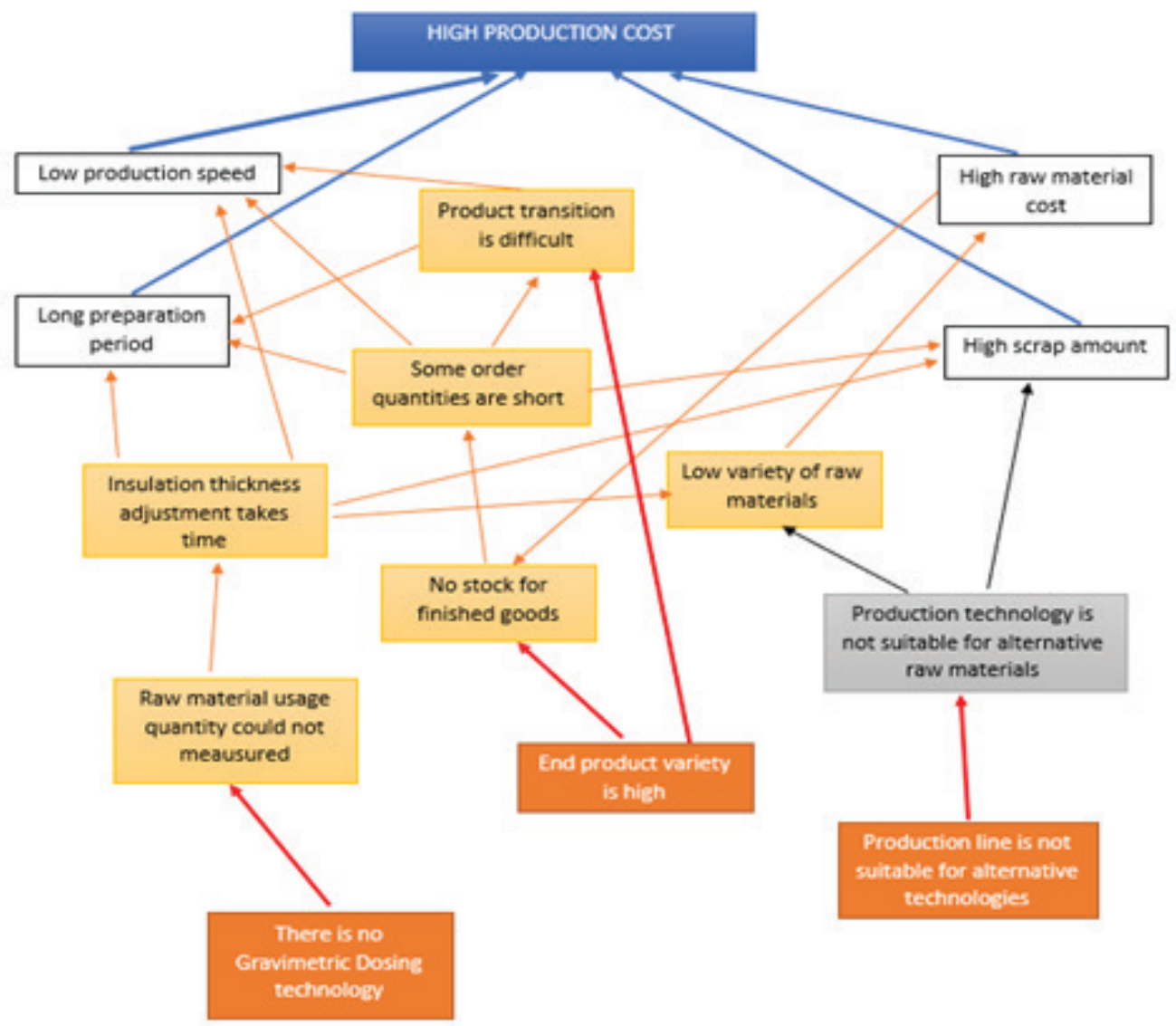

Figure 2. Current Reality Tree

\section{Define}

In this stage, where the starting point of $6 \sigma$, CTQ's will be determined and the most critical ones will be selected. A SIPOC (Supplier-Input-Process-Output-Customer) map was used to make a more detailed description of CTQs (Table 2). With the help of the SIPOC map, customers who are involved in every step of the processes will be listed and critical CTQs can be determined. For this, "voice of the customer" (VOC) analysis will be used (Table 3). 
Table 2

SIPOC MAP

\begin{tabular}{|c|c|c|c|c|}
\hline SUPPLIER & INPUT & PROCESS & OUTPUT & CUSTOMER \\
\hline Quality Control (QC) & $\begin{array}{l}\text { QC approved con- } \\
\text { ductor }\end{array}$ & $\begin{array}{l}\text { Starting point of } \\
\text { Insulation }\end{array}$ & Conductor & MV operator \\
\hline $\begin{array}{l}\text { Semi Conductive Gra- } \\
\text { nule Input }\end{array}$ & $\begin{array}{c}\text { Semi Conductive } \\
\text { Granule }\end{array}$ & \multirow{2}{*}{ Insulation Process } & \multirow{2}{*}{ Insulated core } & \multirow{2}{*}{$\begin{array}{l}\text { QC, Screening Ope- } \\
\text { rator }\end{array}$} \\
\hline $\begin{array}{ll}\text { Insulation } & \text { Material } \\
\text { Supplier } & \\
\end{array}$ & XLPE material & & & \\
\hline MV operator & Insulated Core & $Q C$ & $\begin{array}{l}\text { QC approved insula- } \\
\text { ted core }\end{array}$ & Screening Operator \\
\hline QC & $\begin{array}{l}\text { QC approved insula- } \\
\text { ted core }\end{array}$ & $\begin{array}{l}\text { Starting point of } \\
\text { Screening }\end{array}$ & $\begin{array}{l}\text { Insulated core ready } \\
\text { for screening }\end{array}$ & Screening Operator \\
\hline Copper tape supplier & $\begin{array}{l}\text { Insulated core ready } \\
\text { for screening }\end{array}$ & \multirow{3}{*}{ Screening } & \multirow{3}{*}{ Screened core } & \multirow{3}{*}{$\begin{array}{l}\text { Jacketing line ope- } \\
\text { rator }\end{array}$} \\
\hline \multirow{2}{*}{ Copper wire plant } & Copper tape & & & \\
\hline & Copper wire & & & \\
\hline Screening operator & Screened core & $\begin{array}{c}\text { Starting point of } \\
\text { Jacketing }\end{array}$ & $\begin{array}{l}\text { Screened core ready } \\
\text { for jacketing }\end{array}$ & $\begin{array}{c}\text { Jacketing line ope- } \\
\text { rator }\end{array}$ \\
\hline PE, HDPE supplier & PE, HDPE Granule & \multirow{2}{*}{ Jacketing Process } & \multirow{2}{*}{ Cable } & \multirow{2}{*}{$\begin{array}{c}\text { QC, Packing/Delivery } \\
\text { operator }\end{array}$} \\
\hline PVC plant & PVC Granule & & & \\
\hline Jacketing line operator & Cable & $Q C$ & QC Approved Cable & $\begin{array}{c}\text { Packing/Delivery } \\
\text { Operator }\end{array}$ \\
\hline $\begin{array}{l}\text { Packing/Delivery Ope- } \\
\text { rator }\end{array}$ & QC Approved Cable & Delivery & Packed Cable & External Customer \\
\hline
\end{tabular}

With the intention of doing a VOC analysis, one-on-one interviews were made with customers defined on the SIPOC map. Their expectations and demands regarding the product or product features were listed. Hence, we are focusing on the insulation process of MV production, we listed down related customers and their CTQs related to this process only.

\section{Measurement and Analysis}

So as to determine the reasons for the decrease in sales, MV proposals that did not turn into sales orders between 2017 and 2019 were analyzed. It was determined that 606 requests did not turn into orders in that time. The dominant cause is to be determined by Pareto Analysis. All correspondence between the sales representatives and customers were checked. The reasons were; the price offered was too high (57\%), the order quantity was not sufficient for the production (25\%), the production line was not sufficient for the order (9\%), other items in the project (order) could not be produced $(6 \%)$, could not meet the delivery time requirements (3\%) (Figure 3). As seen in the analysis, the reasons why offers do not turn into orders are high prices and insufficient quantity. 
Table 3

VOCs and related CTQs

\begin{tabular}{|c|c|c|}
\hline Customer & VOC & $C T Q$ \\
\hline \multirow{2}{*}{ QC } & $\begin{array}{l}\text {-Conductor specifications should be consistent } \\
\text { with international standards }\end{array}$ & $\begin{array}{l}\text {-Conductor resistance and weight values sho- } \\
\text { uld be consistent with QC charts and produc- } \\
\text { tion parameters }\end{array}$ \\
\hline & $\begin{array}{l}\text {-Insulation thickness and mechanical proper- } \\
\text { ties should be consistent with international } \\
\text { standards }\end{array}$ & $\begin{array}{l}\text {-Insulation thickness and mechanical properti- } \\
\text { es should comply with standards }\end{array}$ \\
\hline \multirow{4}{*}{ MV Line operator } & -Conductor should be suitable for insulation & $\begin{array}{l}\text {-Surface of conductor should be smooth and } \\
\text { round }\end{array}$ \\
\hline & $\begin{array}{l}\text {-Insulation and semi conductive granules sho- } \\
\text { uld be suitable with line }\end{array}$ & $\begin{array}{l}\text {-All those granules should be suitable to run the } \\
\text { line at maximum capacity and speed. And they } \\
\text { should be cleaned from the extrusion lines after } \\
\text { the production easily }\end{array}$ \\
\hline & $\begin{array}{l}\text {-Single type and brand material should not be } \\
\text { used }\end{array}$ & $\begin{array}{l}\text {-To apply alternative production techniques, } \\
\text { different type of raw materials which can be } \\
\text { easily cleaned should be available }\end{array}$ \\
\hline & $\begin{array}{l}\text { - Quantity of raw material that used at the be- } \\
\text { ginning stage of the production should be ea- } \\
\text { sily measured }\end{array}$ & $\begin{array}{l}\text {-Since the MV line is totally a closed line, in- } \\
\text { sulation thickness could not be measured. With } \\
\text { GD system, thickness could be easily measured } \\
\text { and adjusted. }\end{array}$ \\
\hline Screening Operator & -Insulated core should be suitable for screening & $\begin{array}{l}\text { - Surface of the insulated core should be smo- } \\
\text { oth and round }\end{array}$ \\
\hline $\begin{array}{l}\text { Customers } \\
\text { that give MV orders } \\
\text { (External Customer) }\end{array}$ & $\begin{array}{l}\text {-Best price (lowest one) should be offered } \\
\text {-Quality of product should be consistent with } \\
\text { standards and parameters } \\
\text {-Diameter of cable should be suitable for desig- } \\
\text { ned connectors and plugs. } \\
\text {-Orders should be delivered on time }\end{array}$ & $\begin{array}{l}\text {-Offered price must be the same or lower than } \\
\text { other prices. It must be delivered on time. Cab- } \\
\text { le should meet all quality norms. }\end{array}$ \\
\hline
\end{tabular}

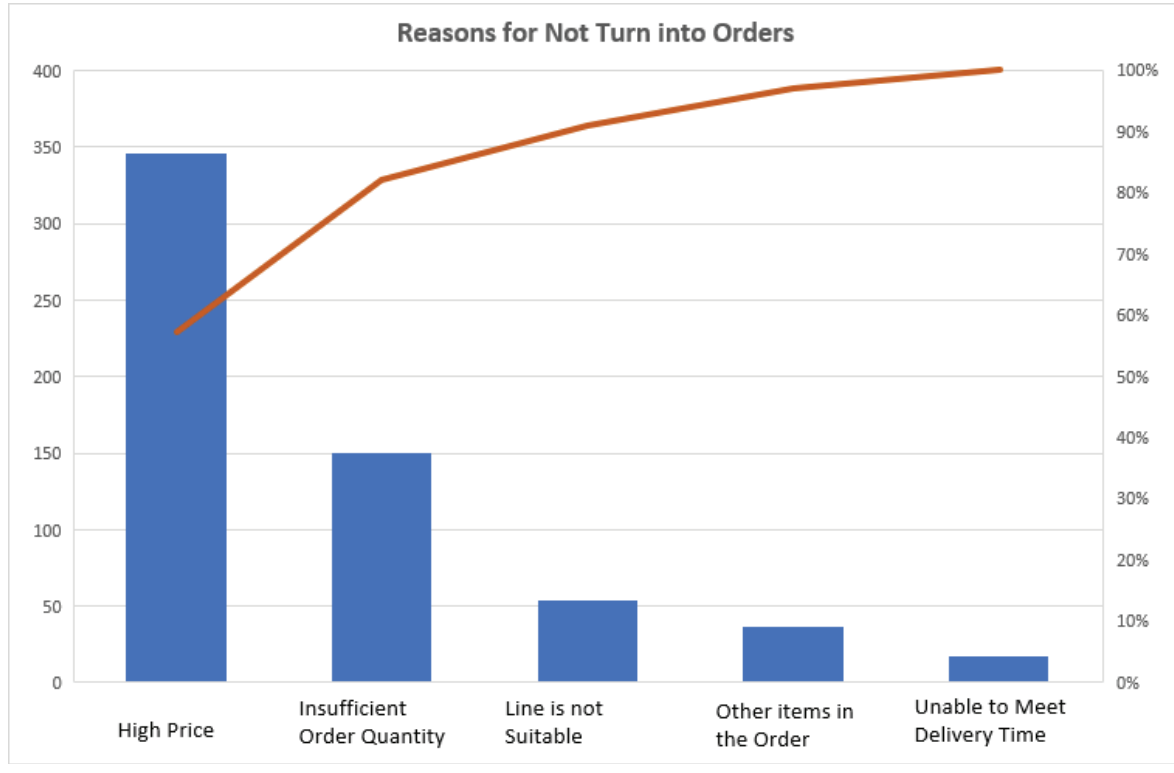

Figure 3. Pareto Analysis 
At this stage, it was attempted to determine the root cause of the high prices by the project team by using a cause - effect diagram (Figure 4). Raw material, labour and energy costs were determined as sub-elements of the product cost. The usage of a single type of material constitutes an obstacle in achieving the targets of an increasing production speed or decreasing the scrap amount and production cost of the enterprise. The reason that was defined in the labour cost was the fact that the inability to control the raw material amount during the production, has a direct effect on production cost.

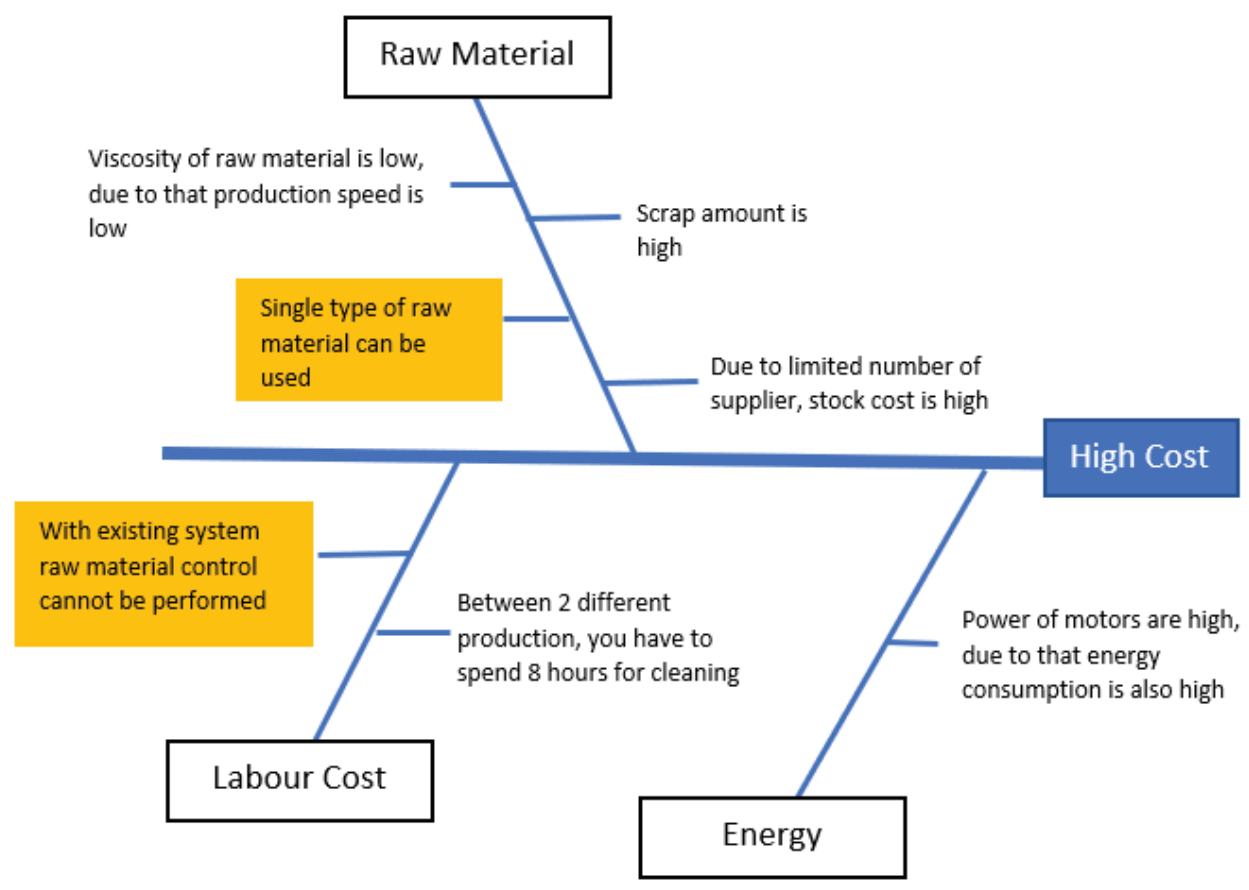

Figure 4. Cause - effect diagram

\section{Exploit and Subordinate to the Constraint}

Defined constraint is a physical constraint. By using a GD system, the thickness of crosslinked polyethylene which forms the insulating layer of cable, will be accurately and consistently controlled during the production. In this way, we prevent excessive usage of material and unnecessary cost increase.

At this stage we examined the cost increase caused by the inability to control the material. We selected copper conductor, $30 \mathrm{kV}$ cable $(\mathrm{Cu} 30 \mathrm{kV})$ which constitutes $33 \%$ of the entire MV business of the company in 2019. The cost of raw materials were defined with the reference value of international standards related to this cable and the cost of raw materials as per recorded in the accounting data base (Table 4). 
Table 4

Raw Material Quantities and Costs determined in cable design /Cu30kV

\begin{tabular}{|c|c|c|c|c|c|}
\hline Raw Material & Thickness (mm) & Quantity $(\mathrm{kg} / \mathrm{km})$ & $\begin{array}{c}\text { Unit Cost (USD/ } \\
\mathrm{kg})\end{array}$ & $\begin{array}{c}\text { Total Cost (USD/ } \\
\mathrm{km})\end{array}$ & $\begin{array}{c}\text { Ratio in Total } \\
\text { Cost (\%) }\end{array}$ \\
\hline Copper & & 2,650 & 6.25 & $16,562.5$ & 82.5 \\
\hline Semi Cond. & 1.05 & 120 & 2.10 & 252 & 1.3 \\
\hline XLPE & 8.00 & 699 & 1.95 & $1,363.1$ & 6.8 \\
\hline Semi Cond. Tape & & 14 & 5.97 & 83.6 & 0.4 \\
\hline Copper Screen & & 225 & 6.35 & $1,428.8$ & 7.1 \\
\hline Non-Cond. Tape & & 11 & 5.57 & 61.3 & 0.3 \\
\hline Jacketing & & 335 & 0.95 & 318.3 & 1.6 \\
\hline TOTAL & & 4,054 & & 20,070 & \\
\hline
\end{tabular}

A flowchart of $8 \mathrm{~km} \mathrm{Cu} 30 \mathrm{kV}$ cable production was collected from an ERP programme that the company use (Table 5). In this chart, the line speed and quantity of the production were detailed. After this production, a sample was taken from the production and insulation layers and they were measured. According to this measurement, the usage of raw materials was calculated (Table 6).

Tablo 5

Flowchart of the Production (Cu30kV $8 \times 1,000 \mathrm{~m})$

\begin{tabular}{|c|c|c|c|c|}
\hline Process & Date & Hour & $\begin{array}{l}\text { Line Speed } \\
(\mathrm{m} / \mathrm{min})\end{array}$ & Quantity (meters) \\
\hline $\begin{array}{l}\text { Starting point of } M V \text { production } \\
\text { (Adjustment of thickness) }\end{array}$ & \multirow[t]{2}{*}{ 11.11.2019 } & $8: 35$ & 3 & 198 \\
\hline Adjustment completed & & 9:41 & & \\
\hline Full Speed Production & 11.11.2019 & $09: 42-5: 59$ & 3.9 & 1,470 \\
\hline Full Speed Production & 11.11 .2019 & $16: 00-3: 59$ & 3.9 & 1,868 \\
\hline Full Speed Production & 12.11 .2019 & $00: 00-7: 59$ & 4.35 & 2,084 \\
\hline Full Speed Production & 12.11.2019 & $08: 00-5: 59$ & 4.35 & 2,084 \\
\hline Full Speed Production & 12.11.2019 & $16: 00-7: 40$ & 3.77 & 376 \\
\hline
\end{tabular}

During routine controls on each MV production process, it was determined that all production parameters were consistent with design parameters. However, due to the reason of the semiconductive and insulation layer being thicker than the design parameter, the cable diameter was increased. In this case the usage of other raw materials was increased.

Table 6

Consumption of Raw Materials $/ 8 \mathrm{~km}(\mathrm{Cu} 30 \mathrm{kV})$

\begin{tabular}{lcc}
\hline Raw Material & Thickness $(\mathbf{m m})$ & Consumption $(\mathbf{k g} / \mathbf{k m})$ \\
\hline Copper & 1.14 & 21,413 \\
Semi Cond. & 9.08 & 1,021 \\
XLPE & & 6,656 \\
Semi Cond. Tape & 117 \\
Copper Screen & & 1,821 \\
Non-Cond. Tape & 95 \\
Jacketing & & 2,843 \\
TOTAL & 33,966 \\
\hline
\end{tabular}


The quantity of raw materials between actual value and quantity that should be used according to design parameters were compared (Table 7). According to this comparison there is a $3.6 \%$ weight difference between the actual value and the design value. With the same unit costs for each raw material, the total cost of $\mathrm{Cu} 30 \mathrm{kV}$ product were calculated and compared with the design cost. The Production cost was determined to be $20,351.48 \mathrm{USD} / \mathrm{km}$ which is $1.4 \%$ more expensive than the design cost calculated previously $(20,070 \mathrm{USD} / \mathrm{km})$.

Considering the $4 \%$ profit margin for the MV product group foreseen by the company, a $1.4 \%$ improvement in raw material costs will provide a good advantage. In light of the information obtained from production workflow chart for $8 \mathrm{~km}$ (Table 5), the average line speed for the total production, including the adjustment stage for the thickness, was calculated as $4.10 \mathrm{~m} / \mathrm{min}$.

Table 7

Weight Differences of Raw Materials between Design and Production (Cu30kV)

\begin{tabular}{lccc}
\hline Raw Material & Design $($ Quantity $\mathbf{k g} / \mathbf{k m})$ & Production $($ Quantity $\mathbf{k g} / \mathbf{k m})$ & $\boldsymbol{D} / \boldsymbol{P} \%$ \\
\hline Copper & 2,650 & 2,650 & 0 \\
Semi Cond. & 120 & 126.36 & 5.3 \\
XLPE & 699 & 823.76 & 17.8 \\
Semi Cond. Tape & 14 & 14.48 & 3.4 \\
Copper Screen & 225 & 225.37 & 0.1 \\
Non-Cond. Tape & 11 & 11.75 & 6.8 \\
Jacketing & 335 & 351.85 & 5 \\
TOTAL & 4,054 & $4,203.57$ & 3.6 \\
\hline
\end{tabular}

According to the information obtained from the production managers, in cases where there is additional time spend for adjustment, $\mathrm{Cu} 30 \mathrm{kV}$ product can be produced at $4.35 \mathrm{~m} /$ min. With this information, by keeping the production account constant the actual and targeted man-hour information was calculated. In addition, the labour productivity rate was also calculated (Kahya \& Karaböcek, 2020, p.3) (Table 8).

Table 8

Actual - Targeted man-hour information (Cu30kV)

\begin{tabular}{lcccc}
\hline & $\begin{array}{c}\text { Q. of Production } \\
(\boldsymbol{m})-\boldsymbol{A}\end{array}$ & $\begin{array}{c}\text { Avr. Speed } \\
(\boldsymbol{m} / \text { min)- } \boldsymbol{B}\end{array}$ & Time(man.hour) $\boldsymbol{A} / \boldsymbol{B}$ & Labour Productivity Rate (LPR) \\
\hline Cu30kV (Production) & 8,080 & 4.10 & 32.85 & $8,080 / 32.85=245.96$ \\
Cu30kV (Target) & 8,080 & 4.35 & 30.95 & $8,080 / 30.95=261.07$ \\
& & & & $261.07 / 245.96 \times 100=6.14 \%$ \\
\hline
\end{tabular}

A $6.14 \%$ increase in productivity will reduce the labour and energy costs of the product. As the cost distribution information determined for the MV cables, and those improvements on raw material, labour and energy costs $1.4 \%$ and $6.14 \%$ respectively, gains from the expenses would reach $1.6 \%$ (Table 9). 
Table 9

Gain from expenses (Cu30kV)

\begin{tabular}{lcccc}
\hline & Raw Material Cost & Labour-Energy Cost & General Expenses & Total Cost \\
\hline Percentage in Total Cost (\%) & 94 & 5 & 1 & \\
Unit Cost (USD/km) & $20, .351 .48$ & $1,082.53$ & 216.50 & $21,650.51$ \\
Improvement Ratio (\%) & 1.4 & 6.14 & & $21,299.12$ \\
New Unit Cost (USD/km) & $20,066.56$ & $1,016.06$ & & 1.6 \\
Average Improvement (\%) & & & & \\
\hline
\end{tabular}

With the use of a GD system, alternative raw materials also can be used instead of XLPE. You can use base material (L1) and two additives (XA1 and XA2) for insulating material. The GD system supplier recommended new recipe for the new application. With this new formula, the cost of $\mathrm{Cu} 30 \mathrm{kV}$ product was calculated again (Table 10).

In order to calculate new total cost with improved labour and energy cost which were calculated before, we use the new raw material cost $(19,654 \mathrm{USD} / \mathrm{km})$ as a base value (Table 11).

Table 10

Updated recipe and Raw Material Cost (Cu30kV)

\begin{tabular}{|c|c|c|c|c|c|}
\hline Raw Material & Thickness (mm) & Quantity $(\mathrm{kg} / \mathrm{km})$ & $\begin{array}{c}\text { Unit Cost (USD/ } \\
\text { kg) }\end{array}$ & $\begin{array}{c}\text { Total Cost (USD/ } \\
\mathrm{km})\end{array}$ & $\begin{array}{c}\text { Ratio in Total } \\
\text { Cost (\%) }\end{array}$ \\
\hline Copper & & 2,650 & 6.25 & $16,562.5$ & 84.27 \\
\hline Semi Cond. & 1.05 & 120 & 2.10 & 252 & 1.2 \\
\hline L1 & & 685 & 1.15 & 787.75 & 4.0 \\
\hline XA1 & 800 & 2 & 30.8 & 61.6 & 0.3 \\
\hline XA2 & 0.00 & 12 & 8.20 & 98.4 & 0.5 \\
\hline Semi Cond. Tape & & 14 & 5.97 & 83.6 & 0.4 \\
\hline Copper Screen & & 225 & 6.35 & $1,428.8$ & 7.3 \\
\hline Non-Cond. Tape & & 11 & 5.57 & 61.3 & 0.3 \\
\hline Jacketing & & 335 & 0.95 & 318.3 & 1.7 \\
\hline TOTAL & & 4,054 & & 19,654 & \\
\hline
\end{tabular}

As a result, either with the use of existing raw materials and recipes to completely control the usage of raw material and production speed (thus achieving 1.6\%), or with the use of new recipes and raw materials (thus achieving 3.55\%) we can reduce our production cost. Hence, the usage of the new recipe provides a better result, it was preferred to commission this new system with the use of new raw materials.

Tablo 11

Updated cost $(\mathrm{Cu} 30 \mathrm{kV})$

\begin{tabular}{lcccc}
\hline & Raw Material & Labour-Energy & General Expenses & Total \\
\hline Percentage in Total Cost (\%) & 94 & 5 & 1 & $21,650.51$ \\
Unit Cost (USD/km) & $20,351.48$ & $1,082.53$ & 216.50 & $20,908.51$ \\
Improvement Ratio (\%) & 19,654 & $1,045.43$ & 209.08 & 3.55 \\
New Unit Cost (USD/km) & & & & 3 \\
\hline
\end{tabular}




\section{Verify Data}

With the purpose of examining the effectiveness of the new system, affected CTQs and VOC's should be listed again (Table 12).

Table 12

CTQs after improvement

\begin{tabular}{|c|c|c|c|}
\hline CUSTOMER & VOC & $C T Q$ & Improvement \\
\hline QC & $\begin{array}{l}\text {-Insulation thickness and mec- } \\
\text { hanical properties should be } \\
\text { consistent with international } \\
\text { standards }\end{array}$ & $\begin{array}{l}\text {-Insulation thickness and } \\
\text { mechanical properties should } \\
\text { comply with standards }\end{array}$ & $\begin{array}{c}\text { - Insulation thickness can be } \\
\text { controlled in every layer with a } \\
\text { GD system }\end{array}$ \\
\hline \multirow[t]{3}{*}{$\begin{array}{l}\text { MV Line } \\
\text { Operator }\end{array}$} & $\begin{array}{c}\text { - Insulation and semi conducti- } \\
\text { ve granules should be suitable } \\
\text { with line }\end{array}$ & $\begin{array}{l}\text { - All those granules should be } \\
\text { suitable to run the line at maxi- } \\
\text { mum capacity and speed, and } \\
\text { they should be cleaned from the } \\
\text { extrusion lines after the produc- } \\
\text { tion easily }\end{array}$ & \multirow{2}{*}{$\begin{array}{l}\text { - New raw materials which } \\
\text { were adopted with a GD system } \\
\text { were cost affective and could } \\
\text { be easily cleaned and removed } \\
\text { from the extrusions }\end{array}$} \\
\hline & $\begin{array}{l}\text { - Single type and brand materi- } \\
\text { al should not be used }\end{array}$ & $\begin{array}{l}\text { - To apply alternative produc- } \\
\text { tion techniques, different type } \\
\text { of raw materials which can } \\
\text { be easily cleaned should be } \\
\text { available }\end{array}$ & \\
\hline & $\begin{array}{l}\text {-- Quantity of raw material that } \\
\text { was used at the beginning stage } \\
\text { of the production should be } \\
\text { easily measured }\end{array}$ & $\begin{array}{l}\text { - Since the MV line is totally a } \\
\text { closed line, the insulation thick- } \\
\text { ness could not be measured. } \\
\text { With a GD system, thickness } \\
\text { could be easily measured and } \\
\text { adjusted. }\end{array}$ & $\begin{array}{l}\text {-With a GD system, the amount } \\
\text { of raw materials determined } \\
\text { in the design can be loaded } \\
\text { exactly, preventing the use of } \\
\text { more materials. }\end{array}$ \\
\hline $\begin{array}{l}\text { Customers that } \\
\text { give MV orders } \\
\text { (External } \\
\text { Customer) }\end{array}$ & $\begin{array}{l}\text {-Best price (the lowest one) } \\
\text { should be offered } \\
\text {-Quality of product should be } \\
\text { consistent with standards and } \\
\text { parameters } \\
\text {-Diameter of cable should be } \\
\text { suitable for designed connec- } \\
\text { tors and plugs. } \\
\text {-Orders should be delivered } \\
\text { on time }\end{array}$ & $\begin{array}{c}\text {-The Offered price must be the } \\
\text { same or lower than other prices. } \\
\text { It must be delivered on time. } \\
\text { Cable should meet all quality } \\
\text { norms. }\end{array}$ & $\begin{array}{l}\text {-We can reach a } 3.55 \% \text { imp- } \\
\text { rovement on production cost. } \\
\text { Thus we can reach prices that } \\
\text { meet customers' expectations. } \\
\text {-As the new production speed } \\
\text { is faster, orders will be comple- } \\
\text { ted on time. }\end{array}$ \\
\hline
\end{tabular}

\section{Improve and Elevate the Constraint}

The GD supplier has made trials on the existing line to demonstrate the reliability and measurement accuracy of the system. The purpose of these trials are to determine the accuracy of material consumption and how the system interferes with the production line when there is a problem in material flow. At this stage Design of Experiment (DOE) was applied to examine the effects on output (Demir, 2004, p.7).

Raw materials L1, XA1 and XA2, are measured with GD and affect the process. In order to define numbers of a sufficient trial, factorial design (FD) will be used. Since raw materials whose effects we will examine are lower or higher than the basic recipe value, we can say that each factor (raw material) has two levels. In that case we can use $2 \mathrm{k}$ FD. Here, "k" indicates 
the number of factor, " 2 " indicates the number of levels. If factors are lower level than the prescription value, it will be shown as "- ", if it is high, it will be shown as "+". Since the number of experiments is 2 and for factors 3 , the number of trial is calculated as $2^{3}=8$.

In trials, the performance of the GD system was evaluated with; how long it takes to give a response for material flow increase of decrease by the system (the expectation is lower than 3 seconds), the line speed in the increase or decrease of the materials, the quality of the product and finally the cost of the product. For each experiment, 5 different, in total 40 trials were made separately, and the levels of raw materials used were determined by taking the arithmetic average of each trial result. The most suitable combination is, MV line speed $(+)$, quality $(+)$, cost $(-)$ and in this combination, GD system responds to material changes less than 3 seconds. Above those 8 experiments, the $7^{\text {th }}$ experiment was found to be the most appropriate one (Table 13).

Table 13

Effects of Factors in DOE

\begin{tabular}{|c|c|c|c|c|c|c|c|c|c|}
\hline & & Trial 1 & Trial 2 & Trial 3 & Trial 4 & Trial 5 & Trial 6 & Trial 7 & Trial 8 \\
\hline \multirow{3}{*}{$\begin{array}{l}\text { Raw } \\
\text { Materials }\end{array}$} & $L 1$ & + & + & + & + & - & - & - & - \\
\hline & $X A 1$ & + & - & + & - & + & - & + & - \\
\hline & $X A 2$ & + & + & - & - & + & + & - & - \\
\hline \multirow{4}{*}{ Assesment } & GD respond (sn) & 2 & 2 & 2 & 1 & 2 & 2 & 1 & 1 \\
\hline & Line Speed & + & - & + & - & + & - & + & - \\
\hline & Quality & + & - & + & - & + & - & + & - \\
\hline & Cost & + & + & + & - & + & + & - & - \\
\hline
\end{tabular}

The total investment cost of the GD system is 111,920 USD. The profitability, continuity and reliability of investments should be evaluated by using economic analysis methods. The main analysis methods are the profitability index method, payback period method, net present value method and internal rate of return method (Saray, 2019, p. 36-39). Due to fragile economic conditions in Turkey, the company should choose the payback period method (PPM) which is a numerical period that shows how long it takes to recover the value spent for investment (Fizibilite info, 2020).

The estimated sales volume of the MV product group for 2020 has been determined as 13 million USD. If there is not any investment, considering the $4 \%$ profit margin, the cost of sales (=total sales / (1+profit margin)) was determined as 12.5 million USD. According to the cost distribution that specified above, the raw material cost would be (94\%) 11.75 million USD, labor and the energy cost would be (5\%) 0.625 million USD, general expenses would be (1\%) 0.125 million USD. With the implementation of an integration model, it has been determined that with a GD system, we could save either $1.6 \%$ with the same recipe or $3.55 \%$ with a new recipe. Based on that information the average saving return is calculated as 318,656 USD. 
According to the PPM formulation (Saray, 2019, p.37) the amount of investment would be covered in less than a year with the earnings to be made in 2020. For this reason, the company has decided to invest.

$$
\begin{aligned}
& \text { Average Saving }(\overline{\mathrm{x}})=\frac{\sum \text { Unit Saving }}{\mathrm{n}} \\
& \text { Average Saving }(\overline{\mathrm{x}})=\frac{\left.\sum \text { (Raw Material Cost } \mathrm{x} \% \text { Improvement }\right)+(\text { Labour\&Energy Cost } \mathrm{x} \% \text { Improvement })}{\mathrm{n}} \\
& P P M=\frac{\text { Amount of Investment }}{\text { Net yearly Earnings }}=\frac{111,920 \text { USD }}{318,656 \text { USD }}=0.35 \text { year }
\end{aligned}
$$

\section{Control and Identification of New Constraints}

With the intention of checking the effectiveness of the GD system, several samples were selected from the actual production and raw material usage and the line speeds were checked. $\mathrm{Cu} 45 \mathrm{kV}$ type of cable was selected. The production parameters and the cost of cables were analyzed (Table 14). According to examination, a 1.55\% improvement has been achieved in the raw material cost and productivity increased by $2.56 \%$.

Additionally, the " $\sigma$ " levels are also calculated and compared considering the Cu45kV's product cost differences with design cost before and after GD system. The company aims to have the product cost lower or at least equal to the design cost. Before the GD system, between 2018 and 2019, there were in total 18 lots of production, and in 2020 between February and August there were 9 . The obtained product costs were listed and compared with the design cost (Table 15).

To calculate " $\sigma$ " levels before and after the system, we can check defects per million opportunities $(\mathrm{DPMO})$ number $(\mathrm{DPMO}=\mathrm{DPOx} 1,000,000)($ Table 16).

\begin{tabular}{|c|c|c|c|c|c|c|}
\hline & Raw Material & $\begin{array}{c}\text { Thickness } \\
\quad(\mathrm{mm})\end{array}$ & $\begin{array}{c}\text { Quantity } \\
(\mathrm{kg} / \mathrm{km})\end{array}$ & $\begin{array}{l}\text { Unit Cost } \\
\text { (USD/kg) }\end{array}$ & $\begin{array}{l}\text { Total Cost } \\
\text { (USD/km) }\end{array}$ & $\begin{array}{c}\text { Speed } \\
(\mathrm{mt} / \mathrm{min})\end{array}$ \\
\hline \multirow{8}{*}{ Design } & Copper & & 3,380 & 6.15 & 20,787 & \multirow{8}{*}{3.12} \\
\hline & Semi Cond. & 1.1 & 150 & 2.12 & 318 & \\
\hline & XLPE & 12 & 1,291 & 1.85 & $2,388.4$ & \\
\hline & Semi Cond. Tape & & 17 & 6.54 & 111.2 & \\
\hline & Copper Screen & & 776 & 6.27 & $4,865.5$ & \\
\hline & Non-Cond. Tape & & 14 & 6.04 & 84.6 & \\
\hline & Jacketing & & 540 & 1.27 & 685.8 & \\
\hline & TOTAL & & 6,168 & & $29,240.5$ & \\
\hline
\end{tabular}

Table 14

Design and Production parameter of $\mathrm{Cu} 45 \mathrm{kV}$ 


\begin{tabular}{|c|c|c|c|c|c|c|}
\hline & Raw Material & $\begin{array}{c}\text { Thickness } \\
(\mathrm{mm})\end{array}$ & $\begin{array}{c}\text { Quantity } \\
(\mathrm{kg} / \mathrm{km})\end{array}$ & $\begin{array}{l}\text { Unit Cost } \\
\text { (USD/kg) }\end{array}$ & $\begin{array}{l}\text { Total Cost } \\
\text { (USD/km) }\end{array}$ & $\begin{array}{c}\text { Speed } \\
(\mathrm{mt} / \mathrm{min})\end{array}$ \\
\hline \multirow{10}{*}{ Production } & Copper & & 3,380 & 6.15 & 20,787 & \multirow{10}{*}{3.20} \\
\hline & Semi Cond. & 1.11 & 165 & 2.12 & 318 & \\
\hline & L1 & \multirow{3}{*}{12.05} & 1,274 & 1.19 & 1,516 & \\
\hline & XA1 & & 4 & 8.6 & 34.4 & \\
\hline & XA2 & & 22 & 17 & 374 & \\
\hline & Semi Cond. Tape & & 17 & 6.54 & 111.2 & \\
\hline & Copper Screen & & 777 & 6.27 & $4,872.8$ & \\
\hline & Non-Cond. Tape & & 15 & 6.04 & 90.6 & \\
\hline & Jacketing & & 542 & 1.27 & 688.3 & \\
\hline & TOTAL & & 6,196 & & $28,792.3$ & \\
\hline Imrovemen & tio & & & & $1.55 \%$ & $2.56 \%$ \\
\hline
\end{tabular}

Table 15

Production costs before and after GD system (Cu45kV)

\begin{tabular}{|c|c|c|c|c|c|c|c|}
\hline & Lot & Cost (USD) & Lot & Cost (USD) & & Lot & Cost (USD) \\
\hline & 1 & $29,650.28$ & 10 & $29,720.56$ & & 1 & $28,792.30 *$ \\
\hline & 2 & $29,230.33 *$ & 11 & $29,230.22 *$ & & 2 & $29,242.00$ \\
\hline & 3 & $29,927.55$ & 12 & $29,980.33$ & & 3 & $28,695.65^{*}$ \\
\hline & 4 & $29,190.68 *$ & 13 & $29,350.68$ & & 4 & $28,800.25^{*}$ \\
\hline \multirow[t]{5}{*}{ Before GD } & 5 & $29,777.56$ & 14 & $29,229.25 *$ & After GD & 5 & $29,257.33$ \\
\hline & 6 & $29,200.65^{*}$ & 15 & $29,331.21$ & & 6 & $28,720.16^{*}$ \\
\hline & 7 & $30,000.58$ & 16 & $29,220.65^{*}$ & & 7 & $28,698.25^{*}$ \\
\hline & 8 & $29,150.20 *$ & 17 & $29,550.28$ & & 8 & $28,820.90^{*}$ \\
\hline & 9 & $29,210.80 *$ & 18 & $30,005.72$ & & 9 & $28,920.90 *$ \\
\hline
\end{tabular}

Tablo 16

\begin{tabular}{lccccc} 
“ $\sigma$ " Level & \multicolumn{1}{c}{$\boldsymbol{\sigma}$} & $\boldsymbol{D P M O}$ & $\boldsymbol{\sigma}$ & $\boldsymbol{D P M O}$ \\
\hline $\boldsymbol{\sigma}$ & $\boldsymbol{D P M O}$ & 2.5 & 158,665 & 1.4 & 539,828 \\
6 & 3.4 & 2.3 & 211,855 & 1.3 & 579,260 \\
5 & 233 & 2.2 & 241,964 & 1 & 691,462 \\
4.5 & 1,350 & 2 & 308,538 & 0.5 & 841,345 \\
4 & 6,210 & 1.8 & 382,089 & 0.3 & 884,930 \\
3.5 & 22,750 & 1.5 & 500,000 & 0.1 & 919,243 \\
3 & 66,807 & & & \\
\hline
\end{tabular}

Ref: (Sağlık Yönetimi 2019, 2020)

In order to calculate DPMO, defects per product (DPU= defective product quantity / total production) and the number of defects per opportunity ( $\mathrm{DPO}=$ defective product quantity / [total production $\mathrm{x}$ number of defect opportunities per unit]) must be determined respectively (Eren B. , 2020). The amount of defective products has been determined as products that have a higher cost than the design cost. A number of defect opportunities is the sum of the features that are characterized as a production failure (Eren B. , 2020). In this process it is " 1 " where the cost of production is higher than design cost (Table 17). 
Table 17

“ $\sigma$ ” Level before and after GD System

\begin{tabular}{|c|c|c|c|c|}
\hline & $D P U$ & DPO & DPMO & $\sigma$ level \\
\hline Before GD & $10 / 18=0.555$ & $10 /(18 \times 1)=0.555$ & $0.555 \times 1,000,000=555,000$ & $1.3-1.4$ \\
\hline After GD & $2 / 9=0.222$ & $2 /(9 \times 1)=0.222$ & $0.222 \times 1,000,000=222,000$ & $2.2-2.3$ \\
\hline
\end{tabular}

While " $\sigma$ " value was between 1.3 and 1.4 before GD system applied, it then reached 2.2 -2.3. As a result of this increase, we can say that after the commissioning of the system, there was an improvement on the process and the " $\sigma$ " value was increased. In addition, during the discussions of management reviews held twice a year, the amount of scrap per MV production has started to decrease since the beginning of 2020. It was 20.74 meters on average per production in 2018, 19.64 meters in 2019 and finally decreased to 16.48 in 2020.

In parallel with the continuous improvement, the screening process which is the next step of the MV production process was reviewed. Screening is the process of applying semi conductive tapes, copper wires and copper tapes over the insulated conductor. According to production parameters and screening process records of $\mathrm{Cu} 45 \mathrm{kV}$, in every single kilometer of the production 58,000 meter $1.36 \mathrm{~mm}$ diameter copper wire and 1,000 meter of copper tape has to be used. At the screening machine, you have to use $160 \mathrm{~mm}$ small plastic reels. $1.36 \mathrm{~mm}$ copper wires are transferred from $630 \mathrm{~mm}$ diameter steel drums to those plastic reels. It takes 290 minutes to transfer $1.36 \mathrm{~mm}$ wires to 58 plastic spools which is necessary to start production.

According to the production records of $11 \times 800$ meter order $\mathrm{Cu} 45 \mathrm{kV}$, it was determined that it takes 140 minutes to screen an 800 meter drum (Table 18). Since 58 plastic spools are emptied at the end of 140 minutes, all new 58 spools will not be ready. It takes around 150 minutes to complete all 58 drums. In this case we can define the wire transfer process as a bottleneck of the screening process. KT and $6 \sigma$ integration model should be reapplied to manage and eliminate this bottleneck.

Table 18

Screening process records (Cu45kV $11 \times 800 \mathrm{~m}$ )

\begin{tabular}{lcccc}
\hline Process & Date & Time & Line Speed & Production \\
\hline Screening process (Wire & 10.05 .2020 & $10: 40-15: 30$ & $100 \mathrm{~m} / \mathrm{min}$ & $58,000 \mathrm{~m} .^{*}$ \\
Transfer) & 10.05 .2020 & $16: 00-18: 20$ & $5.70 \mathrm{~m} / \mathrm{min}$ & $803 \mathrm{~m}$. \\
Screening & 10.05 .2020 & $20: 40-23: 06$ & $5.70 \mathrm{~m} / \mathrm{min}$ & $808 \mathrm{~m}$. \\
Screening & 11.05 .2020 & $01: 20-03: 40$ & $5.70 \mathrm{~m} / \mathrm{min}$ & $805 \mathrm{~m}$. \\
Screening & & &
\end{tabular}

*58.000 m. (Transfer of $1.36 \mathrm{~mm}$ copper wire to 58 plastic spool)

\section{Conclusion}

When the literature was reviewed, TOC and $6 \sigma$ were used separately in process improvement. On the other hand, integration models of each philosophy were limited in the literature. In this study, the integration model of Jin et al. (2009) was reviewed and was applied in an industrial company. The company has a considerable role in low and medium voltage power 
cable manufacturing business. The selected integration model was used to identify and eliminate the reason for the decrease in sales figures in the MV power cable group in the last three years. By applying the integration model, attempts were made to answer the following questions.

- What are the root causes of the decrease in sales figures of the MV product group?

- Whether the integration model of Jin et al. (2009) can help to identify and eliminate these root causes.

- How this elimination will benefit to the company.

In an effort to find an answer to the first question, MV production processes were detailed. Then, a project team consisting of managers from the factory determined that when aiming to offer a competitive sales price, high production costs needed to be reduced. First of all, CRT was used to determine root causes. Then, CTQ's were defined with the help of SIPOC map and VOC analysis. At the definition and analysis step of the integration model, a Pareto analysis and cause-effect diagrams were used. Parameters that cause an increase in the production cost were determined with the help of ERP program records. One of the root causes determined in CRT was "There is no GD system". As a result of analysis, it has been revealed that commissioning a GD system will provide an improvement of $1.56 \%$ to $3.55 \%$ in the production cost. The repayment period of the GD system investment also takes less than a year. It was also proved that the GD system was providing an improvement in production costs and an increase productivity from different production records. In addition, this system also had a positive effect in increasing the $\sigma$ value of the $\mathrm{Cu} 45 \mathrm{kV}$ production cost. It was raised from 1.3-1.4 $\sigma$ to 2.2-2.3 $\sigma$ after the installation of the GD system. At the end, new constraints were defined in the screening process which is the next step of the MV production process and implementation of Jin et al. (2009) integration model was completed.

Although a desired increase was not experienced in the sales figure of the MV product group due to the negative consequences of the Covid-19 pandemic experienced all over the world, profitability was increased compared to the previous years.

With this study, the TOC and $6 \sigma$ integration model of which Jin et al. (2009) developed, was applied to the highly competitive and conservative energy cable manufacturing sector. This model requires the usage of detailed data and information. In this sector all enterprises have their own secrets and details. Due to that, the company requested that the name and some technical information be hidden during this study. Although the application of this model has provided a significant improvement for the company, it is thought that the gains are more than the specified numerical values. This model can also be applied to different process, such as the low voltage production or packing and delivery that have more general process parameters and might be the same for the same industries. 
As a conclusion, the TOC and $6 \sigma$ integration model can be applied to all businesses that want to review their processes and control their production costs and operate in the production or service sector. Thanks to this model, enterprises can make radical changes to their processes and increase their profitability levels above the sector averages that they are in.

\section{Peer-review: Externally peer-reviewed.}

Author Contributions: Conception/Design of study: E.E., M.A.T.; Data Acquisition: E.E.; Data Analysis/Interpretation: E.E., M.A.T.; Drafting Manuscript:E.E., M.A.T.; Critical Revision of Manuscript: M.A.T.; Final Approval and Accountability: E.E., M.A.T.

Conflict of Interest: The authors have no conflict of interest to declare.

Grant Support: The authors declared that this study has received no financial support.

\section{References}

Abid, M., Butt, O. M., Aan, Q., Rashid, B., \& Devi, N. S. (2020). Role of Critical Success Factors (CSF) In the Impelemntation of Six Sigma in Hospitals: A Preliminary Study in Pakistan. Asia-Pasific Journal of Health Management, 15(1), 1-9. https://doi.org/10.24083/apjhm.v15i1.333

Aiastui, A. L., Perez de Eulate, U. A., \& Guisasola, M. M. (2020). A Strategic Approach for Bottleneck Identification in Make-To-Order Environments: A Drum-Buffer-Rope Action Research Based Case Study. Journal of Industrial Engineering and Management, 13(1), 18-37. http://dx.doi.org/10.3926/jiem.2868

Akbulut, H., \& Ertan, S. (2015). Hizmet Sektöründe Kısıtlar Teorisi ve Katkı Muhasebesi: Bir Otel İşletmesinde Uygulama. Muhasebe ve Vergi Uygulamaları Dergisi, 8(3), 243-270.

Akçimen, C., \& Antmen, F. (2019). Kısıtlar Teorisinde Kapasite Kısıtı ve Bir Üretim İşletmesinde Uygulamas1. Avrupa Bilim ve Teknoloji Dergisi, 15, 618-626.

Al-Fasfus, F., Hamza, M., \& Elkotayni, K. (2020). The Attitudes of The Industrial Companies Towards the Implementation of Theory of Constraints (A Field Study). Academy of Strategic Management Journal, 19(2), 1-14.

Alghaithi, A., \& Sartawi, K. (2020). “Improving Remote Employees' Organisational Productivity- Practical Guidelines for Identifying and Managing Bottlenecks in Today's World”. IOSR Journal of Business and Management, 22(2), 63-74. DOI: 10.9790/487X-2202046374

Ali, A. Y. (2020). "Six Sigma-DMAIC and Food Waste Hierarchy based Framework for Reducing Food Waste in University Canteens in Ethiopia”. Int. Journal of Research in Industrial Engineering, 9(1), 77-83. DOI: $10.22105 /$ riej.2020.209160.1105

Antony, J. (2004). "Some Pros and Cons of Six Sigma: An Academic Perspective". The TQM Magazine, 16(4), 303-306.

Ayanoğlu, M., \& Şakar, M. (2015). “Bir Kargo Fimasının Ek Taleplerinin Karşılanması İçin Kısıtlar Kuramı Yaklaşımı Uygulaması”. İşletme Bilimi Dergisi, 3(2), 19-38.

Bircan, H., \& Köse, S. (2012). “Altı Sigma ve Firmaların Altı Sigmaya Bakış Açısı: Sivas-Kayseri İli Örneği”. Ekonomik ve Sosyal Araştırmalar Dergisi, 8(2), 107-129.

Boangmanalu, E., Abigail, T., Sembiring, A., \& Tampubolon, J. (2020). "Minimizing Damage of Product Using Six Sigma and Triz Methods". IOP Conference Series: Materials Science and Engineering (1-8). IOP Publishing. https://iopscience.iop.org/article/10.1088/1757-899X/801/1/012101/pdf 
Coronado, R.B., \& Anthony, J. (2004). "Six Sigma or Design for Six Sigma”. The TQM Magazine, 16(2), 250-263.

Costa, L.B.M., Filho, M.G., Fredendall, L.D., Ganga, G.M.D. (2021), "Lean Six Sigma in the Food Industry: Construct Development and Measurement Validation". International Journal of Production Economics, 231, 107843. https://doi.org/10.1016/j.jipe.2020.107843

Coşkun, O., \& Ekmekçi, İ. (2012). "Bir İnşaat Projesinin Evreleri ile Zaman ve Maliyet Analizinin Proje Yönetim Teknikleri Vasitasıyla İncelenmesi”. İstanbul Ticaret Ünv. Fen Bilimleri Dergisi, 10(20), 39-53.

Çalışkan, G. (2006). “Altı Sigma ve Toplam Kalite Yönetimi”. Elektronik Sosyal Bilimler Dergisi, 5(17), 60-75.

Dakhil, A. (2019). "Development of Effective Methodology for Improving Undergraduate Program Curriculum in Higher Education Utilizing Six Sigma Approach". Ankara: Atılım Üniversitesi. Available from National Thesis Center database (No: 603687)

Demir, L. (2004). “İstatistiksel Deney Tasarım Yöntemi ve Bir Tekstil İşletmesinde Uygulanması”. Denizli: Pamukkale Üniversitesi. Retrived from http://acikerisim.pau.edu.tr/xmlui/bitstream/handle/11499/1215/ Leyla\%20Demir.pdf?sequence=1\&isAllowed=y

Demircioğlu, E. N., \& Akkaya, N. (2016). “Kısıtlar Teorisi 5 Adım Sürekli İyileştirme Sürecinin Boya Sektöründe Uygulaması”. Muhasebe Bilim Dünyası Dergisi, 18(1), 269-295.

Edgeman, R., \& Bigio, D. (2004). “Six Sigma in Metaphor: Heresy or Holy Writ?”. Quality Progress, 37(1), 1-6.

Ehie, I., \& Sheu, C. (2005). "Integrating Six Sigma and Theory of Constraints for Continuous Improvement: A Case Study". Journal of Manufacturing Technology Management, 16(5), 542-553. https://doi. org/10.1108/17410380510600518

Elmacı, O., Uslu, M., \& Tutkavul, K. (2013). "Sürdürülebilir Rekabet Gücünün Sağlanmasında Altı Sigma Yönteminin Kullanılması ve Ford Otomotiv Sanayi A.Ş.' de Bir Uygulama Örneği”, Dumlupınar Üniversitesi Sosyal Bilimler Dergisi, Özel Say1, 465-494.

Erdiller, A., \& Orbak, A.Y., (2005). “Otomotiv Yan Sanayinde Altı Sigma Araçlarının Kullanımı ve Uygulama Örneği”. V. Ulusal Üretim Araştırmaları Sempozyumu, 557-559, İstanbul

Eren, B. “Alt1 sigma seviyesinin hesaplanması. Free Lean Six sigma. Retrived from https:/tr.freeleansixsigma.com/

Escobar, V. G., Vega, P. G., \& Zamora, M.-d. M. (2016). “Applying the Theory of Constraints to the Logistic Service of Medical Records of a Hospital". European Research on Management and Business Economics, 22, 139-146.

Fizibilite Info. Retrived from http://www.fizibilite.info/yatirimin-geri-odeme-suresi/.

Garza, M. E., Garcia, J. A., Gonzales, S. H., Santoyo, E. A., Esquivias, M. T., \& Fernandez, V. F. (2019). "Reduction of Work in Process in Manufacturing Systems by Means of a Theory of Constraints Approach and Discrete Event Simulation". Engineering and Technology Journal, 4(2), 537-544. https://doi. org/10.31142/etj/v4i2.02

Gholami, H., Jamil, N., Mat Saman, M.Z., Streimikiene, D., Sharif, S., Zakuan, N. (2021) "The Application of Green Lean Six Sigma". Business Strategy and the Environment, 30, 1913-1931. https://doi. org $/ 10.1002 /$ bse. 2724

Goldratt, E. M., \& Cox, J. (2018). Amaç [The Goal] (A.B. Dicleli, Trans.). İstanbul, Turkey: Optimist.

Grida, M., \& Zeid, M. (2018). “A System Dynamics-Based Model to Implement The Theory of Constraints in a Healthcare System”. Medical Simulation, 95(7), 593-605. https://doi.org/10.1177/0037549718788953

Harish, U. (2019). "Implementation of Theory of Constraints (TOC) in a Manufacturing Plant". International 
Journal of Advanced Scientific Research and Management, 228-232.

Hsu, Y., Pearn, W.L. \& Wu, P. (2008). “Capability Adjustment for Gamma Processes with Mean Shift Consideration in Implementing Six Sigma Program”. European Journal of Operational Research, Elsevieri vol. 191(2), 517-529, December.

Huang, W-T., Lu, C-C., Dang, J-F. (2021). "Improving the Return Loading Rate Problem in Nortwest China Based on the Theory of Constraints". Mathematics 9(12), 1397. https://doi.org/10.3390/math9121397

Ikumapayi, O. M., Akinlabi, E. T., Mwema, F. M., \& Ogbonna, O. S. (2020). "Six Sigma versus Lean Manufacturing - An Overview". Materials Today: Proceedings, 26(2), 3275-3281. DOI:10.1016/j. matpr.2020.02.986

Jin, K., Abdul-Razzak, H., Elkassabgi, Y., Zhou, H., \& Herrera, A. (2009). "Integrating the Theory of Constraints and Six Sigma in Manufacturing Process Improvement”. International Journal of Social, Behavioral, Educational, Economic, Business and Industrial Engineering, 3(1), 85-89.

Kahya, E., \& Karaböcek, K. "Bir Atölyede Oranlarla İş Gücü Verimlilik (WPMR) Modelinin Tasarımı ve Uygulanması". Silo Tips: Retrived from https://silo.tips/download/br-atlyede-oranlarla-gc-vermllkwpmr-modelnn-tasarimi-ve-uygulamasi

Karakoç, M., \& Şık, E. (2021). "Theory of Constraints: The Application of Wine Production Facility. Ömer Halisdemir Üniversitesi İktisadi ve İdari Bilimler Fakültesi Dergisi, 14(2), 378-395. https://doi. org/10.25287/ohuiibf.703440

Kaygusuz, S. Y. (2005). "Kısıtlar Teorisi: Varsayımlar, Süreç ve Bir Uygulama”. Ankara Üniversitesi SBF Dergisi, 60(4), 133-156.

Kelly, M. C., \& Germain, R. H. (2020). "Applying Theory of Constraints to Timber Harvesting: A Case Study from the Northeast USA". Croatian Journal of Forest Engineering, 41, 59-69. DOI:10.5552/crojfe. 2020.534

Koch, P.N., Yang, R.J., \& Gu, L. (2004). "Design for six sigma through robust optimization”. Structural and Multidisciplinary Optimization, 26, 235-248. https://doi.org/10.1007/s00158-003-0337-0

Kwalk, Y. H., \& Anbari, F. T. (2006). “Benefit, Obstacles and Future of Six Sigma Approach”. Technovation, 26(5-6), 708-715.

Lee, M.-C., \& Chang, T. (2012). "Combination of theory of constraints, root cause analysis and Six Sigma for quality improvement framework". International Journal of Productivity and Quality Management, 10(4), 447-463. DOI:10.1504/IJPQM.2012.049633

Mahdi, Z.H., Abboud, A.H., \& Hussain, B.B. (2021). “The use of Constraints Theory in Managing, Reducing Costs and Improving Profitability (Study in Baghdad Soft Drinks Company). Review of International Geographical Education (RIGEO), 11(5), 3576-3582. DOI:10.48047/rigeo.11.05.243

Mehdizadeh, E., \& Jalili, S. (2019). "An Algorithm Based on Theory of Constraints and Branch and Bound for Solving Integrated Product-Mix-Outsourcing Problem”. Journal of Optimization in Industrial Engineering, 12(1), 167-172. DOI: 10.22094/joie.2018.664.1429

Mishra, A. K. (2020). "Implication of Theory of Constraints in Project Management". International Journal of Advanced Trends in Engineering and Technology, 5(1), 1-13. DOI:10.5281/zenodo.3605056

Nave, D. (2002). "How to Compare Six Sigma, Lean and Theory of Constraints". Quality Progress, 35(3), 73-78.

Ninerola, A., Rebull, M.V., Lara, A.B. (2021). "Six Sigma Literature: A Bibliometric Analysis” Total Quality Management \& Business Excellence, 32(9-10), 959-980, DOI: 10.1080/14783363.2019.1652091 
Nonthaleerak, P., \& Hendry, L. (2006). "Six Sigma: Literature Review and Key Future Research Areas". International Journal of Six Sigma and Competitive Advantage, 2(2), 105-161. DOI:10.1504/IJSSCA.2006.010111

Pyzdek, T. What is Six Sigma. Pyzdek Institute: Retrived from http:/www.pyzdek.com/six-sigma-revolution.htm

Rahman, S.-u. (1998). “Theory of Constraints: A Review of The Philosophy and Its Applications”. International Journal of Operations \& Production Management, 18(4), 336-355. DOI:10.1108/01443579810199720

Rasis, D., Gitlow, H.S., Popovich, E. (2002). "Paper Organizers International: A Fictitious Six Sigma Green Belt Case Study”. II. Quality Engineering, 15(2), 127-145. https://doi.org/10.1081/QEN-120006715

Rebull, M. V., Rullan, R.F., Lara, A. B., \& Ninerola, A. (2020). "Six Sigma for Improving Cash Flow Deficit: A Case Study in the Food Can Manufacturing Industry". International Journal of Lean Six Sigma. Vol. 11 No. 6, 1119-1140. https://doi.org/10.1108/IJLSS-12-2018-0137

Rojas, M. D., Jurado, D. A., \& Londono, L. M. (2018). “Constrains Theory Explained Trough a Serious Game”. International Journal of Applied Engineering Research, 13(18), 13978-13984.

Rowlands, H. (2003). “Six Sigma: A new philosophy or repackaging of old ideas?”. Engineering Management, 13(2), 18-21. https://doi.org/10.1049/em:20030201

Sağlık Yönetimi 2019. Sigma Değerinin Hesaplanması. Sağlıkta Kalite: Retrived from https://kaliteturkiye. wordpress.com/2014/09/11/sigma-seviyesinin-hesaplanmasi/

Saray, E. (2019). Yenilenebilir Enerji Üretim ve Yatırım Maliyetleri Karşılaştırması: Ege Bölgesi Örneği. Denizli: Pamukkale Üniversitesi. Retrived from http://acikerisim.pau.edu.tr/xmlui/bitstream/handle/11499/27994/10311862.pdf?sequence=1\&isAllowed=y

Sarkar, D., Jha, K.N. \& Patel, S. (2021). "Critical Chain Porject Management for a Highway Construction Project with a Focus on Theory of Constraints. International Journal of Construction Management, 21(2), 194-207. DOI: 10.1080/15623599.2018-1512031

Sithole, C., \& Nyembwe, D. (2020). “Application of Six Sigma Framework to Rapid Sand Casting”. RAPSADA 2019 Conference Preceedings, (381-388). South Africa. Abstract retrived from https://site.rapdasa. org/wp-content/uploads/2020/04/381-Sithole.pdf

Sorkun, M. F. (2018). "Improving The Effectiveness of Solid Waste Treatment Plants via Integrated System Approach: A Case Study on Manisa”. MCBÜ Sosyal Bilimler Dergisi, 16(4), 239-268.

Stanivuk, T., Gvozdenovic, T., Mikulicic, J. Z., \& Lukovac, V. (2020). “Application of Six Sigma Model on Efficient use of Vehicle Fleet”. Symmetry, 12(857), 1-20. https://doi.org/10.3390/sym12050857

Taştan, H., \& Demircioğlu, E. (2015). "Düşünme Süreci Araçları ve Kalite Maliyetlerinin Birlikte Kullanılması: Bir Otel İşletmesinde Uygulama”. Muhasebe ve Denetime Bakış (October), 97-112.

Tekin, M., \& Şahin, Ş. (2014). "Kısıtlar Teorisine Göre Sanayi İşletmelerinde Çalışanların Motivasyonu ve İşletme Başarısına Etkisi: PVC Üretim İşletmesi Üzerine Bir Uygulama”. Selçuk Üniversitesi Sosyal Bilimler Enstitüsü Dergisi (Dr. Mehmet Yıldız Özel Sayısı), 209-223.

Turan, H., \& Turan, G. (2019). "Enerji Yönetiminin Başarısında Yalın Altı Sigmanın Etkisi”. Atlas International Refereed Journal on Social Sciences, 5(17), 112-121.

Türkiye İstatistik Kurumu. Retrived from www.tuik.gov.tr/PreTablo.do?alt_id=1022

Türkmen, M. A. (2017). Üretimde Paradigmal Yaklaşımlar Üzerine Değerlendirmeler (1st ed.) [Evaluations on Paradigmal Approaches oin Production]. İstanbul, Turkey: Kriter Yayınevi.

Uluskan, M. (2017). “Türkiye’nin Altı Sigma Uygulama Haritası”. Çukurova Üniversitesi Mühendislik Mi- 
marlık Fakültesi Dergisi, 32(3), 131-143.

Urban, W. (2019). "TOC Implementation in a Medium-Scale Manufacturing System with Diverse Product Rooting”. Production \& Manufacturing Research, 7(1), 178-194. DOI:10.1080/21693277.2019.1616002

Urban, W., \& Rogowska, P. (2018). "The Case Study of Bottlenecks Identification for Practical Implementation to The Theory of Constraints". Multidisciplinary Aspects of Production Engineering, 1(1), 399-405. DOI:10.2478/mape-2018-0051

Ülgen, B. (2014). İşletmelerde Altı Sigma Uygulamalarının Etkinlik Değerlendirmesi. İstanbul: İstanbul Teknik Üniversitesi. Retrived from https://polen.itu.edu.tr/handle/11527/13784

Ünal, E. N., Tanış, V. N., \& Küçüksavaş, N. (2005). "Kısıtlar Teorisi ve Bir Üretim İşletmesinde Uygulama”. Çukurova Üniversitesi Sosyal Bilimler Enstitüsü Dergisi, 14(2), 433-448.

Wolniak, R., Skotnicka-Zasadzien, B., \& Zasadzien, M. (2018). "Application of the Theory of Constraints for Continuous Improvement of a Production Process-Case Study”. DEStech Transactions on Social Science Education and Human Science, 169-173. DOI:10.12783/DTSSEHS/SEME2017718023

Yang, C. (2004). “An Integrated Model of TQM and GE-Six-Sigma”. International Journal of Six Sigma and Competitive Advantage, 1(1), 97-111. DOI:10.1504/IJSSCA.2009.028095

Yükçü, S., \& Yüksel, İ. (2015). "Hastane İşletmelerinde Kısıtlar Teorisi Yaklaşımı ve Örnek Bir Uygulama”. İktisadi ve İdari Bilimler Dergisi, 29(3), 557-578. 
